\title{
A Comparative Study of Children's Knowledge, Attitudes, and Practices Regarding COVID-19 at Secondary Schools
}

\author{
Hanaa Ibrahim El Sayed ${ }^{1} \quad$ Azza Ismail El Sayed ${ }^{2} \quad$ Safaa Tawfik Almanzalwi ${ }^{3}$ \\ 1.Assistant Professor of Pediatric Nursing, Faculty of Nursing, Menoufia University, Egypt \\ 2.Lecturer of Pediatric Nursing, Faculty of Nursing, Suez Canal University, Egypt \\ 3.Lecturer of Community Health Nursing, Faculty of Nursing, Menoufia University, Egypt \\ Corresponding Author’s E-mail: hanaaahmed15@yahoo.com
}

\begin{abstract}
Background: Novel coronavirus-2019 is a highly infectious disease that caused a global pandemic around the world. The aim of this study was to compare the knowledge, attitude, and practice of secondary school children toward COVID-19 in Egypt, and Saudi Arabia. Design: A comparative cross-sectional research was utilized in the present study among secondary school children and conducted from January to April 2021. Settings: The research was conducted on secondary school children at Menoufia Governorate, Egypt, and Jeddah, Saudi Arabia. Sample: All available students of secondary school children (200) were included in the study. A structured online self-reported questionnaire sheet was used to assess children's knowledge, attitude, and practice about COVID-19. Results: It was shown that the mean \pm SD of age for Egyptian children were 15 .96 and the majority of them $(63 \%)$ were female, while the mean \pm SD for Saudi Arabian children were $16 \pm 1.5$ and the entire sample was female (100\%). Conclusion: The majority of Egyptian and Saudi children had correct knowledge and a positive attitude however; there was incompetent practice toward the prevention of the COVID-19 pandemic. Also, there were statistically significant differences among both groups concerning COVID-19. Recommendation: Awareness educational programs should be implemented on a regular basis to foster a positive attitude and good practice toward preventive measures of COVID-19.
\end{abstract}

Keywords: Children, Knowledge, Attitude, Practice, and COVID-19.

DOI: $10.7176 / \mathrm{JHMN} / 95-01$

Publication date: November $30^{\text {th }} 2021$

\section{Introduction}

Coronavirus disease (COVID-19) is a global pandemic caused by the severe acute respiratory syndrome Coronavirus 2 (SARS-CoV-2) $(1,2)$. Person-to-person transmission of COVID-19 occurs through respiratory droplets and contact (3). Since SARS-CoV-2 has been found in the feces of patients in China and the United States, there is a risk of fecal-oral transmission (4). The sources of infection are patients with symptomatic COVID-19 and asymptomatic patients and patients who are carriers of SARS-CoV-2 (5). The incubation period for the virus is typically $2-14$ days, and the period from the onset of symptoms to death was estimated to range from 6 to 41 days (6). As of $9^{\text {th }}$ January 2021, there have been more than 87.3 million confirmed cases of COVID-19 and more than 1.89 million deaths globally (7).

The symptoms of COVID-19 infection include fatigue, cough, fever, sore throat, and myalgia. In severe cases, it can cause pneumonia, respiratory failure, cardiac arrest, and death (8). However, it is estimated that in some studies, $30 \%$ and up to $70 \%$ of patients may be infected with the virus without showing symptoms of illness $(9,10,11)$. Diagnostic testing in symptomatic patients is a nasal swab polymerase chain reaction and chest X-ray can show signs of viral pneumonia or pleural effusion. Many patients will have shortness of breath and may need an electrocardiogram to evaluate for cardiac injury or other causes of shortness of breathing (12). COVID-19 treatment is largely supportive. Most treatments can be done at home. This includes rest, adequate fluid intake, and incentive spirometry or breathing exercises. Quarantining or isolating at home to prevent spread is of the utmost importance (13). Symptomatic management and supportive interventions can be used such as antipyretics, oxygen administration, vitamins, minerals, and supplements, and antibacterial drug administration (14). Severe and critical cases may need Intensive Care Unit admission, high flow oxygen administration, mechanical ventilation, convalescent plasma administration, and glucocorticoid therapy (15).

Compliance with preventive measures is very important to prevent the spread of disease. It may be affected by the public's awareness and attitude towards COVID-19 (16). There is evidence that public knowledge is important for responding to epidemics $(17,18)$. By assessing the public's awareness and knowledge of the coronavirus, deeper insights into existing public perceptions and practices can be obtained, which can help determine the attributes that influence the public's adoption of health practices and response behaviors (19). World Health Organization (WHO) has recommended strategies to control the pandemic, such as cancellation of social events, traffic restriction, home quarantine, and development of clinical care. In addition to management policies, laboratory capacity enhancement, surveillance strategies, infection prevention, implementation of health measures for travelers risk communications, and community engagement (20). 
The COVID-19 outbreak is a worldwide traumatic event, creating a unique and unprecedented change in health care systems (21). Therefore, nursing care should focus on limiting the exposure and spread of the virus. Control practices are used to provide safe, quality supportive care and education (22). Nurses' interventions include history taking, triage, sample collection, administration of drugs as prescribed for symptomatic management such as antipyretic for fever, antibiotics for associated bacterial infection, oxygen administration to sustain $\mathrm{Spo} 2>90 \%(21,23)$.

\section{Operational definitions}

○ Children are young individuals with expected physical, emotional, and mental abilities (ages $14-19$ ).

- Knowledge is awareness or understanding of facts.

- Attitude is a set of emotions, beliefs, and behaviors toward a particular event.

- Practice is the act of doing something regularly to improve the skills at doing it.

- COVID-19 is a potentially severe, primarily respiratory illness caused by a coronavirus.

\section{Aim of the study:}

The aim of the current study is to compare the knowledge, attitude, and practice of secondary school children about COVID-19 in Egypt and Saudi Arabia.

\section{Objectives}

1. To compare the knowledge of secondary school children regarding COVID-19 includes mode of transmission, clinical manifestations, treatment, precautions, and risk groups.

2. To recognize the attitude of secondary school children regarding COVID-19 including social distance, hand washing, and the methods of controlling the infection.

3. To recognize the practice of secondary school children toward prevention of COVID -19 infection includes cultural behavior, social distance, and hand washing.

\section{Material and Methods}

Research Design: A comparative cross-sectional research design was utilized in the present study via a webbased survey to assess the level of KAP among secondary school students in Egyptians and Saudi Arabia regarding COVID-19.

\section{Setting:}

This study was conducted at Secondary Schools in Menofia governorate, Egypt, and Jeddah, Saudi Arabia.

\section{Sampling:}

In this study, a systemic random sample was used to include secondary school children in the above-mentioned settings (200 Child).

Inclusion criteria: The inclusion criteria for sampling were:

1) Secondary school children who are available during the collection of data.

Exclusion criteria:

1) Secondary school children who didn't complete the answers to the questionnaire sheet.

\section{Tool of data collection}

One tool was used for data collection:

Tool: A structured online self-reported questionnaire sheet was implemented by using a Web-based survey platform. It was adapted from previously validated research (23) and composed of four parts:

Part 1: Socio-demographic data are collected including age, gender, nationality, and attendance of training programs about COVID-19.

Part 2: Knowledge regarding COVID-19 had 15 questions. These questions were responded on a Yes / No basis. The correct answer received one and the incorrect answer received zero. Adequate knowledge equal to $\geq 75 \%$ of the total score and $<75 \%-60 \%$ was deemed moderately adequate knowledge while $<60 \%$ of the total score was revealed poor knowledge.

Part 3: The attitude concerning the prevention of COVID-19 had 5 questions. The grading system is based on a 5-point Likert scale that ranges from (strongly disagree $=1)$, (disagree $=2)$, (uncertain $=3$ ), $($ agree $=4)$ to (strongly agree $=5$ ). Favorable perception is $\geq 60$ percent of total score, whereas $<60 \%$ is considered unfavorable.

Part 4: Practice headed for COVID-19 had 5 questions. These questions were answered on a Yes / No basis. The result was expressed as a percentage. Incompetent practice: $<85 \%$ of entire practices score, while competent practice: $\geq 85 \%$ of total practice score. 


\section{Ethical considerations}

Following an explanation of the purpose that participation in the study is voluntary, local authorities granted authorization to conduct the study. Those who agreed to participate in the study gave their informed consent. The collected information was kept secret.

\section{Procedure for data collection}

Fieldwork: Data collection was conducted from January to April 2021.

\section{Assessment phase}

Official permission was approved from the appropriate authoritative personnel. The questionnaire was converted to an online web-based survey. Before administration, the web-based survey was experienced on different web browsers to ensure robustness. Secondary school children who agreed to contribute in the study were interviewed through Zoom meetings according to their available time. The researchers illuminated to the students the purpose of the study and asked them to fill out the questionnaire (tooll) through Google form and it took 15 minutes. A message with a link to the web-based survey was sent to the class leaders to invite all the registered students to share in the study. The assessment phase took four months to complete the required data.

\section{Data processing and analysis}

The IBM Statistical Package of Social Science (SPSS) version 26 was used to analyze the data. Descriptive statistics were used to resume the students' responses to the KAP statements in the form of frequencies, percentages, means, and standard deviations in the form of frequency distribution tables, numbers, and percentages.

\section{Results}

Table (1): Socio-demographic characteristic of studied children ( $N=200)$

\begin{tabular}{|c|c|c|c|c|c|}
\hline \multirow{2}{*}{\multicolumn{2}{|c|}{ Demographic characteristic }} & \multicolumn{2}{|c|}{$\begin{array}{c}\text { Egyptian students } \\
(\mathrm{No}=\mathbf{1 0 0})\end{array}$} & \multicolumn{2}{|c|}{\begin{tabular}{|c} 
Saudi Arabian students \\
$(\mathrm{No}=\mathbf{1 0 0})$
\end{tabular}} \\
\hline & & No & $\%$ & No & $\%$ \\
\hline \multirow{2}{*}{\multicolumn{2}{|c|}{$\begin{array}{cc}\text { 1-Children Age: } & \\
\bullet & 14-< \\
\bullet & 16-< \\
\bullet & \geq 18\end{array}$}} & $\begin{array}{l}51 \\
42 \\
7 \\
\end{array}$ & $\begin{array}{l}51 \\
42 \\
7 \\
\end{array}$ & $\begin{array}{l}14 \\
66 \\
20 \\
\end{array}$ & $\begin{array}{l}14 \\
66 \\
20 \\
\end{array}$ \\
\hline & & \multicolumn{2}{|c|}{ Mean \pm SD : $15 \pm .96$} & \multicolumn{2}{|c|}{ Mean $\pm \mathrm{SD}=16 \pm 1.5$} \\
\hline $\begin{array}{r}2-\text { Sex } \\
\bullet \\
\bullet \\
\end{array}$ & $\begin{array}{l}\text { Male } \\
\text { Female }\end{array}$ & $\begin{array}{l}37 \\
63 \\
\end{array}$ & $\begin{array}{l}37 \\
63 \\
\end{array}$ & $\begin{array}{l}0.0 \\
100 \\
\end{array}$ & $\begin{array}{l}0.0 \\
100 \\
\end{array}$ \\
\hline $\begin{array}{r}\text { 3-Nati } \\
\bullet \\
\bullet \\
\end{array}$ & $\begin{array}{l}\text { Egyptian students } \\
\text { Saudi Arabian }\end{array}$ & $\begin{array}{l}100 \\
100 \\
\end{array}$ & $\begin{array}{l}100 \\
100 \\
\end{array}$ & $\begin{array}{l}100 \\
100 \\
\end{array}$ & \begin{tabular}{|l|}
100 \\
10 \\
\end{tabular} \\
\hline $\begin{array}{r}\text { 4-Pre } \\
\bullet \\
\bullet \\
\end{array}$ & $\begin{array}{l}\text { rograms } \\
\text { Yes } \\
\text { No } \\
\end{array}$ & \begin{tabular}{|l|}
0 \\
100 \\
\end{tabular} & $\begin{array}{l}0 \\
100\end{array}$ & $\begin{array}{l}6 \\
94\end{array}$ & $\begin{array}{l}6 \\
94\end{array}$ \\
\hline
\end{tabular}

Table 1: displayed the distribution of the studied children according to their socio-demographic characteristics. It was shown that the mean \pm SD of age for Egyptian students were $15 \pm .96$ and the majority of them $(63 \%)$ were female, while the mean \pm SD for Saudi Arabian students were $16 \pm 1.5$ and the entire sample was female (100\%). Regarding attendance of previous training about COVID-19, it was illustrated that none of Egyptian children attending any previous program and only $6 \%$ of Saudi Arabian students was attending previous training programs. 
Figure (1): Distribution of the studied children according to their age

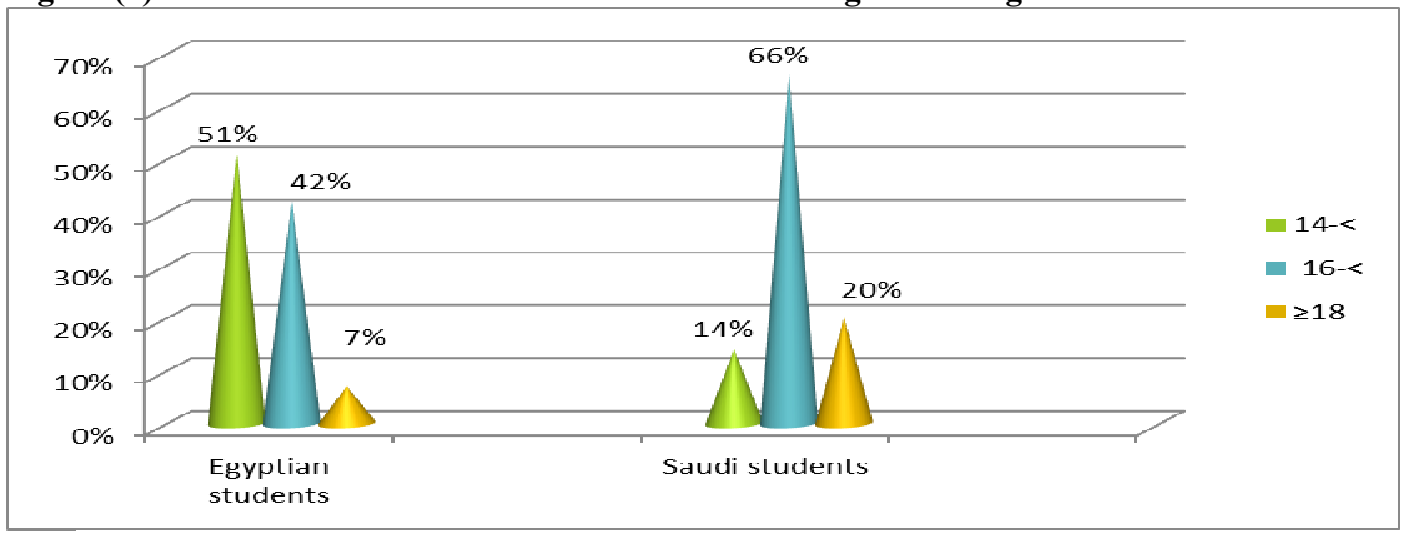

Figure 1 represented the distribution of the studied children according to their age, it was noted that more than half of secondary Egyptian children (51\%) were aged $14-<16$, while the proportion of Saudi students $(66 \%)$ were aged between $16-<18$ years old.

Table (2): Responses of students to knowledge regarding COVID -19 (No=200).

\begin{tabular}{|c|c|c|c|c|c|}
\hline \multirow[t]{2}{*}{ Statements } & \multicolumn{2}{|c|}{$\begin{array}{c}\text { Egyptian students } \\
(n=100) \\
\end{array}$} & \multicolumn{2}{|c|}{$\begin{array}{c}\text { Saudi Arabian students } \\
(\mathrm{n}=\mathbf{1 0 0})\end{array}$} & \multirow[t]{2}{*}{$P$ value } \\
\hline & $\begin{array}{l}\text { Correct } \\
\text { Answer } \\
\end{array}$ & \begin{tabular}{|l|} 
Incorrect \\
Answer \\
\end{tabular} & $\begin{array}{l}\text { Correct } \\
\text { Answer }\end{array}$ & $\begin{array}{l}\text { Incorrect } \\
\text { Answer }\end{array}$ & \\
\hline $\begin{array}{l}\text { 1- COVID-19 spreads from individual-to-individual } \\
\text { within close distance of each other }\end{array}$ & $88 \%$ & $12 \%$ & $100 \%$ & $0 \%$ & $.000 *$ \\
\hline $\begin{array}{l}\text { 2- COVID-19 spread via respiratory droplets, like } \\
\text { coughing and sneezing }\end{array}$ & $93 \%$ & $7 \%$ & $91 . \%$ & $9 \%$ & $.602 \mathrm{~ns}$ \\
\hline $\begin{array}{l}\text { 3- COVID-19 can be contracted by touching a } \\
\text { contaminated surface, followed by touching one's } \\
\text { mouth, nose, or eyes. }\end{array}$ & $46 \%$ & $54 \%$ & $79 \%$ & $21 \%$ & $.000^{*}$ \\
\hline $\begin{array}{l}\text { 4-Close contact or ingesting wild animals causes } \\
\text { COVID }-19 \text {. }\end{array}$ & $42 \%$ & $58 \%$ & $87 \%$ & $13 \%$ & $.000 *$ \\
\hline $\begin{array}{l}\text { 5-People infected with COVID-19 can't transmit the } \\
\text { virus to others while a fever is not present. }\end{array}$ & $92 \%$ & $8 \%$ & $90 \%$ & $10 \%$ & $.621 \mathrm{~ns}$ \\
\hline $\begin{array}{l}\text { 6-The main symptoms of COVID -19 are fatigue, fever, } \\
\text { dry cough, shortness of breath, and myalgia }\end{array}$ & $94 \%$ & $6 \%$ & $65 \%$ & $35 \%$ & $.000^{*}$ \\
\hline 7-Antibiotics are an effective treatment for COVID -19 . & $96 \%$ & $4 \%$ & $62 \%$ & $38 \%$ & $.000 *$ \\
\hline \begin{tabular}{lllll|}
$8-$ People with serious chronic illnesses & are at \\
increased risk of developing & more & serious \\
complications from COVID -19 & & \\
\end{tabular} & $66 \%$ & $34 \%$ & $80 \%$ & $20 \%$ & $.026 \mathrm{~ns}$ \\
\hline $\begin{array}{l}\text { 9-Children appear to be at higher risk for COVID -19 } \\
\text { than adults. }\end{array}$ & $98 \%$ & $2 \%$ & $74 \%$ & $26 \%$ & $.000^{*}$ \\
\hline $\begin{array}{l}\text { 10-It is essential for children to take measures to avoid } \\
\text { COVID - } 19 \text { transmissions. }\end{array}$ & $100 \%$ & $0 \%$ & $95 \%$ & $5 \%$ & $.024 \mathrm{~ns}$ \\
\hline $\begin{array}{l}\text { 11-People should avoid touching their eyes, nose, and } \\
\text { mouth with unwashed hands. }\end{array}$ & $95 \%$ & $5 \%$ & $80 \%$ & $20 \%$ & $.001 * *$ \\
\hline $\begin{array}{l}\text { 12-People should put on a mask if they are infected } \\
\text { with the virus or caring for somebody with suspected } \\
\text { COVID-19 infection }\end{array}$ & $96 \%$ & $4 \%$ & $98 \%$ & $2 \%$ & $.407 \mathrm{~ns}$ \\
\hline $\begin{array}{l}\text { 13-Isolation and treatment of people infected with the } \\
\text { COVID-19 are effective methods to decrease infection }\end{array}$ & $97 \%$ & $3 \%$ & $87 \%$ & $13 \%$ & $.000 *$ \\
\hline $\begin{array}{l}\text { 14-People in contact with someone infected with } \\
\text { COVID - } 19 \text { should be immediately quarantined, in an } \\
\text { appropriate location, for an observational period of } 14 \\
\text { days }\end{array}$ & $98 \%$ & $2 \%$ & $76 \%$ & $24 \%$ & $.000 *$ \\
\hline $\begin{array}{l}\text { 15- To prevent transmission of COVID-19, people } \\
\text { must avoid going to crowded places and avoid taking } \\
\text { public transport. }\end{array}$ & $94 \%$ & $6 \%$ & $90 \%$ & $10 \%$ & $.600^{*}$ \\
\hline
\end{tabular}


Table 2: clarified the responses of children to knowledge regarding COVID -19, it was illustrated that the mean COVID-19 knowledge score for Egyptian students was 12.07, and the overall accuracy rate for the knowledge test was $83.93 \%$. While the mean COVID-19 knowledge score of Saudi Arabian students was 12.59, and the overall accuracy rate for the knowledge test was $84.6 \%$ indicating correct knowledge for both Egyptian and Saudi children. The majority of Egyptian and Saudi Arabian children had correct knowledge regarding COVID-19. However, less than half of Egyptian students had correct knowledge concerning the transmission of infection is occurred by touching a contaminated surface followed by touching one's mouth, nose, or eyes (46\%). In addition to $42 \%$ of them reported that close contact or ingesting wild animals causes COVID-19. However, these results were different in Saudi Arabia, it was revealed that the majority are responded correctly (79\% and $87 \%$ respectively). Therefore, there were statistically significant differences in knowledge among Egyptian and Saudi Arabian children regarding COVID-19.

Table (3) Attitude of the children towards COVID-19 $(\mathrm{No}=\mathbf{2 0 0})$

\begin{tabular}{|c|c|c|c|}
\hline \multirow[t]{2}{*}{ Statements } & $\begin{array}{c}\text { Egyptian } \\
\text { students } \\
\text { No=100 } \\
\end{array}$ & $\begin{array}{c}\text { Saudi Arabian } \\
\text { students } \\
\text { No }=\mathbf{1 0 0} \\
\end{array}$ & \multirow[t]{2}{*}{$\begin{array}{c}\mathbf{P} \\
\text { value }\end{array}$} \\
\hline & $\%$ & $\%$ & \\
\hline $\begin{array}{l}\text { 1- It is important to keep distance from others to avoid the spread } \\
\text { of COVID -19 } \\
\text { Strongly agree } \\
\text { Agree } \\
\text { Neutral } \\
\text { Disagree } \\
\text { Strongly disagree }\end{array}$ & $\begin{array}{c}64 \\
32 \\
4 \\
0 \\
0\end{array}$ & $\begin{array}{c}39 \\
44 \\
9 \\
6 \\
2 \\
\end{array}$ & $.001 * *$ \\
\hline $\begin{array}{l}\text { 2-Hand washing is an effective measure against COVID-19. } \\
\text { Strongly agree } \\
\text { Agree } \\
\text { Neutral } \\
\text { Disagree } \\
\text { Strongly disagree }\end{array}$ & $\begin{array}{c}64 \\
30 \\
6 \\
5 \\
2 \\
\end{array}$ & $\begin{array}{c}86 \\
14 \\
0 \\
0 \\
0 \\
\end{array}$ & $.001 * *$ \\
\hline $\begin{array}{l}\text { 3-To protect myself from COVID-19 exposure, I should stay } \\
\text { home or receive medical care while } \\
\text { I am sick. } \\
\text { Strongly agree } \\
\text { Agree } \\
\text { Neutral } \\
\text { Disagree } \\
\text { Strongly disagree }\end{array}$ & $\begin{array}{c}53 \\
34 \\
13 \\
0 \\
0 \\
\end{array}$ & $\begin{array}{c}82 \\
16 \\
2 \\
0.0 \\
0.0 \\
\end{array}$ & $.000 *$ \\
\hline $\begin{array}{l}\text { 4-COVID-19 will eventually be controlled successfully } \\
\text { Strongly agree } \\
\text { Agree } \\
\text { Neutral } \\
\text { Disagree } \\
\text { Strongly disagree }\end{array}$ & $\begin{array}{c}65 \\
30 \\
5 \\
0.0 \\
0.0 \\
\end{array}$ & $\begin{array}{c}88 \\
10 \\
2 \\
0 \\
0 \\
\end{array}$ & $.000^{*}$ \\
\hline $\begin{array}{l}\text { 5-Compliance with the precautionary measures of the Ministry of } \\
\text { Health will prevent the spread of COVID19. } \\
\text { Strongly agree } \\
\text { Agree } \\
\text { Neutral } \\
\text { Disagree } \\
\text { Strongly disagree }\end{array}$ & $\begin{array}{c}7 \\
69 \\
20 \\
0.0 \\
4\end{array}$ & $\begin{array}{c}47 \\
31 \\
22 \\
0 \\
0\end{array}$ & $.000^{*}$ \\
\hline
\end{tabular}

Table 2: clarified attitude of the children towards COVID-19, it was revealed that the mean attitude score for Egyptian children was 21.69, and the overall perce ption was $88.8 \%$ indicating positive attitudes. Also, it was revealed that the mean attitude score for Saudi children COVID-19 was 21.72 and the overall favorable perception was $89 \%$ indicating positive attitudes for both Egyptian and Saudi children. The majority of Egyptian and Saudi Arabian children had a positive attitude concerning keeping distance from others to avoid the spreading of COVID-19 and staying at home during the pandemic period. Both Egyptian and Saudi children were agreed that COVID-19 will be successfully controlled and compliance with the Ministry of Health 
precautions prevents the spread of infection. There were statistically significant differences in attitude among Egyptian and Saudi Arabian children concerning COVID-19.

Figure (2): Perception of Egyptian and Saudi Arabian children about hand washing as an effective protective measure against COVID-19.

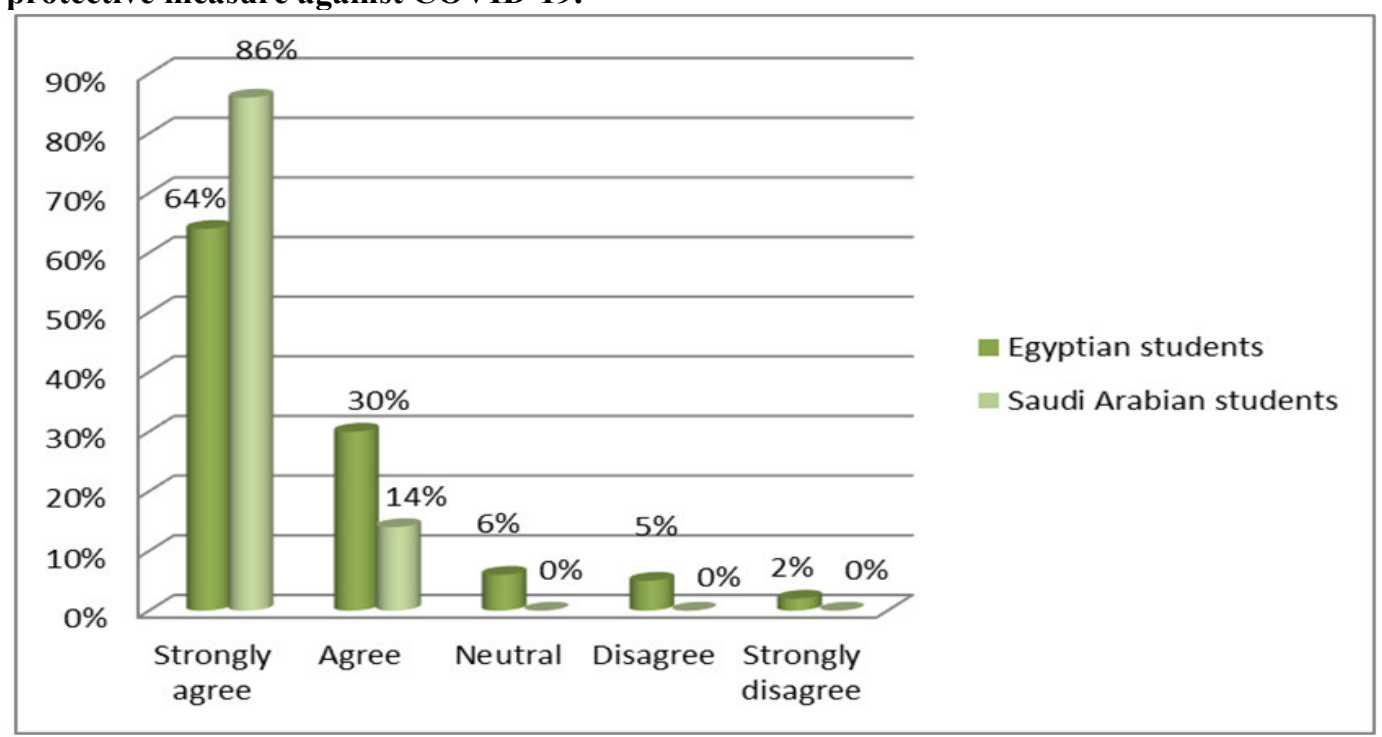

Figure (2): Perception of Egyptian and Saudi Arabian children about hand washing as an effective protective measure against COVID-19. It was revealed that the majority of Egyptian and Saudi Arabian students had a positive attitude concerning hand washing as an effective protective measure against COVID-19.

Table (4): Practice for preventing Covid-19 transmission $(\mathrm{No}=\mathbf{2 0 0})$

\begin{tabular}{|c|c|c|c|c|c|}
\hline \multirow[t]{2}{*}{ Statements } & \multicolumn{2}{|c|}{$\begin{array}{l}\text { Egyptian } \\
\text { students } \\
(\text { No }=100) \\
\end{array}$} & \multicolumn{2}{|c|}{$\begin{array}{l}\text { Saudi Arabian } \\
\text { students } \\
(\mathrm{No}=\mathbf{1 0 0}) \\
\end{array}$} & \multirow[t]{2}{*}{ P value } \\
\hline & Yes. & No & Yes & No & \\
\hline $\begin{array}{l}\text { Have you recently participated in a social event with a large } \\
\text { number of people? }\end{array}$ & $9 \%$ & $91 \%$ & $11 \%$ & $89 \%$ & $.000^{*}$ \\
\hline Have you been to a crowded place recently? & $35 \%$ & $65 \%$ & $24 \%$ & $76 \%$ & $.000 *$ \\
\hline $\begin{array}{l}\text { Have you avoided cultural behaviors such as shaking hands } \\
\text { recently? }\end{array}$ & $60 \%$ & $40 \%$ & $70 \%$ & $30 \%$ & $.047 \mathrm{~ns}$ \\
\hline Are you practicing social distancing? & $71 \%$ & $29 \%$ & $93 \%$ & $7 \%$ & $.327 \mathrm{~ns}$ \\
\hline $\begin{array}{l}\text { Recently, are you often wash your hands with soap and water } \\
\text { for at least } 40 \text { seconds, especially after going to public places, } \\
\text { or after -blowing your nose, coughing, or sneezing? }\end{array}$ & $77 \%$ & $23 \%$ & $91 \%$ & $9 \%$ & $.002 * *$ \\
\hline
\end{tabular}

Table 4: represented practice for preventing COVID-19 transmission, it was illustrated that the mean score of practices for Egyptian children was 3.52 and the overall practice score was $72.40 \%$. Whereas, the mean score of students in Saudi Arabia, was 3.62 and the overall practice score was $73.40 \%$ indicating incompetent practices for both groups. In Egypt, the majority of children reported that they didn't involve in social events with a large number of people and avoiding crowded places (91\% and 65\% respectively). These results are in line with the results of Saudi Arabian children who revealed that the majority of them didn't involve in social events and avoiding crowded places (89\% and $76 \%$ respectively). In Saudi Arabia, the majority of children are practicing social distancing and washing their hands with soap and water (93\% and $91 \%$ respectively) compared to Egyptian children $(71 \%$ and $71 \%$ respectively) therefore, there were statistically significant differences in practice among Egyptian and Saudi Arabian children about COVID-19.

\section{Discussion}

The coronavirus disease is a highly infectious disease that has caused a global pandemic and poses a significant threat to public health. In our study, it was shown that the mean \pm SD of age for Egyptian children were $15 \pm .96$ and the mean \pm SD for Saudi Arabian children were $16 \pm 1.5$. The study revealed that more than half of secondary Egyptian children $(51 \%)$ were aged $14-<16$, while the proportion of Saudi children $(66 \%)$ were aged between $16-<18$ years old. These results were consistent with (13) who reported that the age of participants ranges from 14 to 19 years old, with a mean \pm SD equal to $17 \pm 3.64$. This finding is similar to (14) who stated that the mean 
age of the respondents was 14.8 years. This age emphasizes the importance of delivering educational programs on pandemic numbers in order to avoid infection spread and enhance the quality of life.

Regarding the distribution of the studied children according to their gender, it was revealed that the majority of Egyptian children were female (63\%). This was in line with a study conducted by (13) revealed that $59.3 \%$ were female and $40.7 \%$ were male. As well as, 15 who stated that $65.5 \%$ were female vs. $34.5 \%$ were males. This was contradicted with results of Saudi children who showed that the entire sample was female (100\%) and this is rendered to the distribution of students at schools according to their gender. Regarding attendance of previous training about COVID-19, it was illustrated that none of Egyptian students attending any previous program, and only $6 \%$ of Saudi Arabian students were attending previous training programs. This clarifies the importance of applying educational programs to increase their awareness about preventive measures and prevent further infection. This is corroborated with (12) who recommended health education interventions to the vulnerable population at risk of contracting COVID-19 to have better knowledge and practices.

Concerning responses of children to knowledge regarding COVID-19, it was shown that the mean COVID19 knowledge score of Egyptian students was 12.07, and the overall accuracy rate for the knowledge test was 83.93\%. While the mean COVID-19 knowledge score of Saudi Arabia children was 12.59, and the overall accuracy rate for the knowledge test was $84.6 \%$ indicating adequate knowledge for both groups. Our results agree with (12) who reported that the overall accuracy rate for the knowledge test was $81.64 \%$. The majority of Egyptian and Saudi Arabian children had correct knowledge regarding COVID-19. Similarly, 23 claimed that the findings indicated that the majority of study participants were familiar with COVID-19. Also, this finding is almost in line with studies 24, 25, and 26 who reported that the Saudi community has enough understanding about epidemics. This may be rendered to the provision of health teaching and awareness through Mass Media and telemedicine that facilitate the provision of health awareness that is very important for early quarantine to prevent the possible spread among the student community. Therefore a study conducted by 27 recommended that new applications and digital platforms during the pandemic facilitating the provision of health services including telemedicine and telecare.

The study revealed that the majority of children in Saudi Arabian and Egypt are identified that people with serious chronic illnesses are at increased risk of developing more serious complications $(80 \%$ and $66 \%$ respectively). This was similar to (12), who found that $95.5 \%$ of the respondents in the study said that persons with chronic conditions are more likely to experience major consequences using COVID-19. However, less than half of Egyptian students had correct knowledge concerning transmission of infection through touching a contaminated surface followed by touching one's mouth, nose, or eyes (46\%). In addition to $42 \%$ of them reported that close contact or ingesting wild animals causes COVID-19. This was in line with (28) who mentioned that only $52.2 \%$ of students answered it correctly. However, these results were different in Saudi Arabia, it was revealed that the majority are responded correctly ( $79 \%$ and $87 \%$ respectively). Therefore, there were statistically significant differences in knowledge among Egyptian and Saudi Arabian students regarding COVID-19. This differentiation in knowledge may be rendered to access to information through the media and social networks and this will emphasize the value of educational initiatives to improve knowledge and awareness. This was consistent with 30 who stated that social media was the main source of knowledge about COVID-19 for $80.8 \%$ of the participants.

In this study, the results revealed that the mean attitude score for Egyptian children was 21.69 , and the overall perception was $88.8 \%$ indicating positive attitudes. Also, it was revealed that the mean attitude score for Saudi children COVID-19 was 21.72 and the overall favorable perception was $89 \%$ indicating positive attitudes. Meanwhile, a study conducted by (23) reported that the mean attitude score for COVID-19 was 28.23 representing positive attitudes. The possible suggestion for such variations may be rendered to variations of sample characteristics. The majority of Egyptian and Saudi Arabian children were keeping their distance from others to avoid the spreading of COVID-19. This is contradicted with (31) who reported that more than half of the children avoid contact with unhealthy people and keeping distance from others (57.4\%). It was revealed that the majority of Egyptian and Saudi Arabian children had a positive attitude concerning handwashing as an effective protective measure against COVID-19. Similarly, 32 concluded that the children had a positive attitude toward the disease preventive measures towards COVID-19 (90\%). Also, this finding agrees with results from (30) who found that most of the children had a positive attitude toward preventive measures including hand washing. This was reversed with (31) who reported that hand washes with soap and water were used as a prevention and control of the disease $(59.4 \%)$ similarly these results founded by $(34,35)$. These proactive strategies from children may attribute to awareness gained from mass media and independent learning about the importance of hand washing and methods of reducing the spread of infection.

Concerning practice for preventing COVID-19 transmission, it was illustrated that the mean score of practices for Egyptian children was 3.52 and the overall practice score was $72.40 \%$. Whereas, the mean score of children in Saudi Arabia, was 3.62 and the overall practice score was $73.4 \%$ indicating incompetent practices for both groups. This was corresponding with (36) who stated that the overall practice of respondents was $65.9 \%$. In 
Egypt, the majority of children reported that they didn't involve in social events with a large number of people and avoiding crowded places (91\% and 65\% respectively). These results are in line with the results of Saudi children who revealed that the majority of them didn't involve in social events and avoiding crowded places (89\% and $76 \%$ respectively). This was corresponding with a study conducted in Egypt mentioned that the students were likely to avoid visiting crowded places $(37,38)$. Also, 22 stated that $96.4 \%$ of the participants avoided crowded places and $98 \%$ wore masks on leaving home. This high compliance to preventive measures was attributed to the health awareness through mass media about prevention and control measures.

The study depicted that $60 \%$ of the Egyptian children are avoided cultural behaviors such as shaking hands compared to $70 \%$ of Saudi children. This finding aligns with (40) who showed that $87 \%$ of them were practicing preventive measures positively. In Saudi Arabia, the majority of children are practicing social distancing and washing their hands with soap and water (93\% and 91\% respectively) compared to Egyptian children (71\% and $71 \%$ respectively) therefore, there were statistically significant differences in practice among Egyptian and Saudi Arabian children. This was similar to (36) who stated that there was sufficient hand hygiene practice among all participants $(87.5 \%)$. This result agreed with (32) who mentioned that $87 \%$ of participants practicing preventive measures positively as avoiding shaking hands and frequently washing their hands. This may be rendered to the information given about handwashing practice by all campaigns during the peak periods of infectious diseases transmission as one of the effective World Health Organization (WHO) recommendations for tackling the virus spread. This was comparable to the findings of (38) who revealed that during periods of infectious disease transmission, campaigns encourage people to wash their hands.

\section{Limitations}

The study had a limited number of limitations. First, the study can be conducted to a large group of secondary school children. Second, being an online survey, we depend on the children who completed the online questionnaire sheet entirely.

\section{Conclusion}

It was concluded that the majority of the study sample had adequate knowledge, and a positive attitude towards the preventive measures of COVID-19. Meanwhile, there was incompetent practice toward preventive measures of COVID-19.

\section{Recommendations}

The following recommendations are based on the study's findings:

- Awareness creation for preventive behaviors should be implemented on a regular basis to promote good knowledge, positive attitude, and good practice in COVID-19 prevention.

○ Development of telecommunication technology is required to facilitate and sustain effective distance communication with children is recommended during the pandemic

- Inspire the availability of telemedicine and tele-delivery of supports services for children is recommended during the pandemic.

- E-learning infrastructure including distance learning platforms should be taken into consideration to facilitate distance learning sessions.

- Similar study can be repeated on a large sample to generalize the findings.

\section{Acknowledgment}

We are very grateful to all the study participants for cooperation in the study and for providing the needed information for conducting this study.

\section{Reference}

1. Palese, A., Papastavrou E, and Sermeus, W. (2021) Challenges and opportunities in health care and nursing management research in times of COVID-19 outbreak .Journal of nursing management. DOI: 10.1111/jonm.13299. Retrieved from https://online library. wiley. Com /journal/13652834

2. Deng, SQ, and Peng, HJ. (2020). Characteristics of and public health responses to the coronavirus disease 2019 outbreak in China. J Clin Med; 9 (2):575.10. 3390 /jcm 9020575.

3. Special Expert Group for Control of the Epidemic of Novel Coronavirus Pneumonia of the Chinese Preventive Medicine Association [An update on the epidemiological characteristics of novel coronavirus pneumonia (COVID-19). (2020). Chin J Epidemiol. 41:139-44. doi: 10.3760/cma. [PubMed] [CrossRef] [Google Scholar].

4. Holshue, M.L, DeBolt, C., Lindquist, S., Lofy KH., Wiesman, J, and Bruce, H .(2020). First case of 2019 novel coronavirus in the United States. $N$ Engl J Med. (2020). 382:929-36. doi: 10.1056/NEJMoa2001191. [ [PubMed] [CrossRef] [Google Scholar] 
5. Chan, JF., Yuan, S., Kok, KH., Chu, H, and Yang J. (2020). A familial cluster of pneumonia associated with the 2019 novel coronavirus indicating person-to-person transmission: a study of a family cluster. Lancet.395:514-23. doi: 10.1016/S0140 6736(20)30154-9. [PMC free article] [PubMed] [CrossRef] [Google Scholar]

6. Wang W., Tang, J, and Wei, F. (2020). Updated understanding of the outbreak of 2019 novel coronavirus (2019-nCoV) in Wuhan, China. $J$ Med Virol.92:441-7. doi: 10.1002/jmv.25689. [PMC free article] [PubMed] [CrossRef] [Google Scholar]

7. World Health Organization. (2021). Coronavirus disease (COVID-19) dashboard; January 10, 2021. Available from: https://covid19.who.int/table. Accessed January 11, 2021.

8. Chen, N., Zhou, M, and Dong, X. (2020). Epidemiological and clinical characteristics of 99 cases of 2019 novel coronavirus pneumonia in Wuhan, China: a descriptive study. Lancet ; 395(10223):507-513. doi:10.1016/S0140-6736(20)30211-7

9. Wong, R. (2020). The SARS-CoV-2 outbreak: an epidemiological and clinical perspective. SN Compr Clin Med. 2020;2:1983-1991.

10. Nishiura, H., Kobayashi, T, and Miyama, T. (2020). Estimation of the asymptomatic ratio of novel coronavirus infections (COVID-19). Int J Infect Dis. 2020; 94:154-155. doi:10.1016/j.ijid.2020.03.020

11. Mizumoto, K., Kagaya, K., Zarebsk,i A, and Chowell, G. (2020). Estimating the asymptomatic proportion of coronavirus disease 2019 (COVID-19). Euro Surveill. 2020 ;25(10): 2000180. doi:10.2807/15607917.ES.2020.25.10.2000180.

12. Fang, Y., Zhang, H, and Xie, J. (2020). Sensitivity of chest CT for COVID-19: comparison to RT-PCR. Radiology. Published online February 19. Retrieved from https: //doi. org/ 10.1148/ radiol.2020200432

13. Caputo, N., Strayer, R, and Levitan, R. (2020). Early self-proning in awake, non-intubated patients in the emergency department: A single ED's experience during the COVID-19 pandemic. Acad Emerg Med. 2020; 27(5):375-378. doi: 10.1111 /acem. 13994. [PMC free article] [PubMed] [CrossRef] [Google Scholar].

14. Shen, C., Wang, Z, and Zhao, F. (2020). Treatment of 5 critically ill patients with COVID-19 with convalescent plasma. JAMA. 2020;323(16):1582-1589. doi: 10.1001/ jama. 2020. 4783. [PMC free article] [PubMed] [CrossRef] [Google Scholar]

15. Hassan, SA., Sheikh, FN., Jamal, S., Ezeh, JK, and Akhtar A. (2020). Coronavirus (COVID-19): A Review of Clinical Features, Diagnosis, and Treatment. Cureus [Internet] 2020 Mar [Cited 2020 Apr 11]; 12(3): e7355. doi:10.7759/cureus.7355

16. Abdelhafiz, A., Mohammed, Z., Ibrahim, M., Ziady, H., Alorabi, M., Ayad, M and Sultan, A. (2020). Knowledge, Attitude and Practice toward COVID-19 among the Public in the Kingdom of Saudi Arabia: A Cross-Sectional Study. Published online 2020 May 27. 10.3389/fpubh.2020.00217PMCID: PMC7266869

17. Chirwa, G. (2019). Socio-economic Inequality in Comprehensive Knowledge about HIV in Malawi. Malawi Med J. (2019) 31:104-11. doi: 10.4314/mmj.v31i2.1. PubMed Abstract|CrossRef Full Text | Google Scholar

18. Podder, D., Paul, B., Dasgupta, A., Bandyopadhyay, L., Pal, A, and Roy, S. (2019). Community perception and risk reduction practices toward malaria and dengue: a mixed-method study in slums of Chetla, Kolkata. Ind J Public Health. (2019) 63:178. doi: 10.4103/ijph.IJPH_321_19. PubMed Abstract | CrossRef Full Text | Google Scholar

19. Adhikari, SP., Meng, S., Wu, Y., Mao, Y., Ye, R, and Wang, Q . (2020). A literature review of 2019 novel coronavirus during the early outbreak period: epidemiology, causes, clinical manifestation and diagnosis, prevention and control. Infect Dis Poverty. (2020) 9:1-12. doi: 10.20944/preprints202002.0060.v1

20. Rugarabamu, S., Ibrahim, M and Byanaku, A. (2020). Knowledge, attitudes, and practices (KAP) towards COVID-19: A quick online cross-sectional survey among Tanzanian residents.

21. Munster, VJ., Koopmans, M., Dormagen, N., Riel, D and Wit, E. (2020). A Novel Coronavirus Emerging in China - Key Questions for Impact Assessment. N Engl J Med. 2020; 382:692-4. [PubMed] [Google Scholar]

22. Lopez, V., Sum, K., Ching, Y and Wong J. (2020). Nursing care of patients with severe acute respiratory syndrome in the intensive care unit?: case reports in Hong Kong. Int J Nurs Stud [Cited 2020 Apr 11];41:263-72. doi: 10.1016/S0020-7489(03)00137-8

23. Al-Hanawi, M., Angawi, K., Alshareef, M., Qattan, A., Helmy, H., Abudawood, Y., Alqurashi, M., Kattan,W., Kadasah, N., Chirwa, G and Alsharqi, M.(2020). Knowledge, Attitude and Practice Toward COVID-19 Among the Public in the Kingdom of Saudi Arabia: A Cross-Sectional Study

24. Al-Mohrej, OA., Al-Shirian, SD., Al-Otaibi, SK., Tamim, HM., Masuadi, EM and Fakhoury, HM. (2016). Is the Saudi public aware of Middle East respiratory syndrome? J Infect Public Health. 9:259-66. doi: 10.1016/j.jiph.2015.10.003. PubMed Abstract | CrossRef Full Text | Google Scholar

25. Aldowyan, N., Abdallah, AS, and El-Gharabawy, R. (2017). Knowledge, Attitude and Practice (KAP) Study about Middle East Respiratory Syndrome Coronavirus (MERS-CoV) among Population in Saudi 
Arabia. International Archives of Medicine (2017). doi: 10.3823/2524

26. Mannan, A and Farhana, KM. (2020). Knowledge and perception toward s Novel Coronavirus (COVID 19) in Bangladesh. Munich Personal RePEc Archive. 6(2): 76-87. Available at https://mpra.ub.unimuenchen.de/99656.

27. Hassounah, M., Raheel, H, and Alhefzi, M. ( 2020). Digital response during the COVID-19 pandemic in Saudi Arabia. J Med Internet Res. 2020;22(9):e19338. doi: 10. 2196/19338

28. Alrasheedy, A., Abdulsalim, S., Farooqui, M., Alsahali, S, and Godman, B.(2020). Knowledge, Attitude and Practice About Coronavirus Disease (COVID-19) Pandemic and Its Psychological Impact on Students and Their Studies: A Cross-Sectional Study Among Pharmacy Students in Saudi Arabia. Risk Management and Healthcare Policy. February 2021 Volume 2021:14 Pages 729_741

29. Khasawneh, A., Humeidan, A, and Alsulaiman, J. (2020). Medical students and COVID-19: knowledge, Attitudes, and Precautionary Measures. A descriptive study from Jordan. Front Public Health. 8:253. doi:10.3389/fpubh.2020.00253

30. Kasemy, Z., Bahbah, B., Zewain, S ., Haggag, M., Alkalash, S., Zahran, E and El Desouky, D. (2020). Knowledge, Attitude and Practice toward COVID-19 among Egyptians J Epidemiol Glob Health. Retrieved from https: //pubmed. ncbi. nlm.nih. gov/ 33009730/

31. Subedi, D., Bhandari, S., Gaire, A., Kandel, M, and Karki. S. (2020). Knowledge, Attitude, and Practices Associated with COVID-19. International Journal of medical student. | Sep-Dec | Vol: 8 | Issue 3. DOI 10.5195/ijms.2020.669

32. Khalil, N., Al-Yuzbaki, D, and Tawfeeq, R. (2020). COVID-19 knowledge, attitude and practice among medical undergraduate students in Baghdad City. Eurasia J Biosci 14: 4179-4186.

33. Souli, D and Dilucca, M. (2020). Knowledge, attitude and practice of secondary school students toward COVID-19 epidemic in Italy: a cross sectional study. : Retrieved from https://doi.org/10.1101/2020.05.08.084236

34. Alzoubi, H., Alnawaiseh, N., Al-Mnayyis, A., Abu- Lubad, M., Aqel, A, and Al-Shagahin, H. (2020). COVID-19 - Knowledge, Attitude and Practice among Medical and Non-Medical University Students in Jordan. J. Pure Appl. Microbiol.14 (1), 17-24. doi: 10.22207/JPAM.14.1.04

35. Peng, Y., Pei, C., Zheng, Y., Wang, J., Zhang, K., Zheng, Z, and Zhu, P. (2020). Knowledge, Attitude and Practice Associated with COVID-19 among University Students: a Cross-Sectional Survey in China. BMC Public Health. [preprint].doi10.21203/rs.3.rs-21185/v1

36. Mahmoud, A., Ahmed, S., Abdalla, A., Mohamed, H, and Khalid, M. (2020). Knowledge, attitude and practice regarding COVID-19 among Sudanese population during the early days of the pandemic: Online cross-sectional survey. Scientific African. Volume 10, November 2020, e00652. Retrieved from https: //www. sciencedirect.com

37. Zhong, BL., Luo, W., Li, HM., Zhang, QQ., Liu, XG and Li, WT. (2020). Knowledge, attitudes, and practices towards COVID-19 among Chinese residents during the rapid rise period of the COVID19 outbreak: a quick online cross-sectional survey. Int J Biol Sci 2020;16;1745-52

38. Kmal, N, and Seedhom, AE. (2011). Knowledge, attitude and practice of El-Minia university students towards pandemic H1N1, Egypt. (2009). JPublic Health. 2011; 19:505-10. doi: 10.1007/s10389-011-04271. [CrossRef] [Google Scholar]

39. Alahdal, H., Basingab, F, and Alotaibi, R. (2020). An analytical study on the awareness, attitude and practice during the COVID-19 pandemic in Riyadh, Saudi Arabia. J Infect Public Health. 2020;13 (10):1446-1452. doi:10.1016/j.jiph.2020.06.015

40. Park, JH., Cheong, HK., Son, DY, and Kim, SU. (2010). Perceptions and behaviors related to hand hygiene for the prevention of H1N1 influenza transmission among Korean university students during the peak pandemic period. BMC Infect Dis. 2010;10:222. doi: 10.1186/1471-2334-10-222. [PubMed] [Google Scholar]. 